LIAMES, Campinas, SP, v. 19, 1-18, e019004, 2019

\title{
Demorphologization of the proto-arawakan privative *ma- in Terena ${ }^{1}$
}

\author{
Fernando O. de Carvalho \\ Universidade Federal do Amapá (UNIFAP, Brasil) \\ https://orcid.org/0000-0002-2115-7416
}

"No matter how remotely, all phonemes were once morphemes, and 'today's phonology is yesterday's morphology",

Hopper (1994: 31)

ABSTRACT: This paper discusses the etymology of two lexical items of Terena, an Arawakan language from southwestern Brazil. Etymologization of the nouns mojénoti 'orphan' and mofêu 'barren, sterile' shows that they preserve traces of the Proto-Arawakan Privative prefix *ma-, now demorphologized as part of synchronically unanalyzable roots. Since PA *ma- is reflected as mo- in Pre-Terena, Proto-Mojeño and Baure, the present work also provides evidence for the shared development $* a>o$, of still unclear conditioning, for the Bolivia-Paraná subgroup of the Arawakan language family, improving on an earlier formulation by Payne (1991). The paper also advances new lexical reconstructions to Proto-Mojeño, addresses phonological developments in Terena and Baure, and compares remnant cognate Gender-marking affixes in both Terena and Proto-Mojeño. Finally, a direct implication of the postulation of a Privative *mo- for a Pre-Terena stage is that the hypothesis that PA *ma- > $o$ - in Terena, advanced by Danielsen, Dunn \& Muysken (2011), can be safely rejected.

KEYWORDs: Arawakan languages; Etymology; Morphology; Phonogenesis.

RESUMO: Este trabalho investiga a etimologia de dois itens lexicais do Terena, uma língua Aruaque do sudoeste do Brasil. A etimologização dos nomes mojénoti "órfão" e mofêu "estéril" demonstra que os mesmos preservam traços do prefixo Privativo *ma- reconstruído para o Proto-Aruaque, como parte sincronicamente não segmentável de raízes. Já que PA *ma- tem o reflexo mo- em Pre-Terena, em Proto-Mojeño e em Baure, apresentamos também evidência para um desenvolvimento PA *a>o, de condicionamento ainda não esclarecido, como um desenvolvimento do subgrupo Bolívia-Paraná, aprimorando a discussão original de Payne (1991). $\mathrm{O}$ artigo também apresenta reconstruções lexicais adicionais para o Proto-Mojeño, trata de desenvolvimentos fonológicos no Terena e no Baure e compara afixos marcadores de Gênero, cognatos, porém morfologicamente reanalisados, em Terena e em Proto-Mojeño. Por fim, uma implicação direta destes achados é a de que a hipótese de que PA *ma- $>o$ ocorreu em Terena, avançada por Danielsen, Dunn \& Muysken (2011), pode ser seguramente abandonada.

PALAVRAS-CHAVE: Línguas Aruaques; Etimologia; Morfologia; Fonogênese.

${ }^{1}$ I am grateful to Françoise Rose for discussion of relevant issues and for her comments on a draft version of this paper. These have helped improve the paper, yet any remaining shortcomings are, of course, my own. 


\title{
1. Introduction
}

The present paper exemplifies how etymological investigation offers an explicit and privileged entry point to an understanding of diachronic morphology, notably as it concerns the obsolescence or loss of specific morphological elements. The inextricable and mutually beneficial relation between etymological investigation and diachronic morphology shows up quite conspicuously in the best studies in the field of etymology (see e.g. Malkiel 1954, 1976 for general statements) and this fruitful interplay has become a topic of explicit discussion in some recent literature (see e.g. Koch 2003; Koch \& Hercus 2013). Due to its dual role as stepping stone for generalizations on language change and as a discipline concerned with the diachrony of particular items and constructions, etymology is able to foreground developments not based on regular, phonetically grounded sound change, including analogical reformation and generalization, morpheme mergers and the loss or shift of morphological boundaries.

Terena, a member of the Arawakan language family spoken in southwestern Brazil, is often presented as a language that has lost specific morphological formatives that are assumed to hark back to the Proto-Arawakan (PA) language - all of this in spite of the fact that Terena, along with other typical members of the family, harbors great morphological complexity (Payne 1991: 376; Aikhenvald 1999: 80). See (1) for a working internal classification of Terena, and tables 1 and 2 for its phonological segmental inventories. ${ }^{2}$

(1) Internal classification of Terena in the Arawakan language family (after Payne 1991: 489; Carvalho 2017c: 71).

\author{
Bolívia-Paraná subgroup \\ * Terena \\ * Mojeño (Ignaciano, Trinitario, Javeriano, Loretano, Old Mojeño) \\ * Paunaka \\ * Baure (Joaquiniano, Carmelito, Baure) \\ * Paikoneka
}

${ }^{2}$ Two diacritic marks, the circumflex mark '^’ and the acute mark ',', are usually employed in presenting Terena data (see e.g. Ekdahl \& Butler 1969, 1979; Carvalho 2017a, b and references therein). These two marks indicate 'greater prominence' on the syllable they occur, differing, however, in terms of their pitch (tonal) and duration properties. The circumflex diacritic indicates greater length of the vowel where it occurs, in addition to a descending pitch curve (tâki ['tà:ki] 'his/her arm'). The acute mark has no particularly salient pitch contour, and its lengthening effect is realized on the following consonant, not on the vowel above which it occurs (ásurupi ['as:urupi] 'guts, intestines'). 
Table 1: Terena Consonants

\begin{tabular}{lccccc}
\hline & Labial & Alveolar & Palatal & Velar & Glottal \\
\hline Stop & $\mathrm{p}$ & $\mathrm{t}$ & & $\mathrm{k}$ & ? \\
Fricative & & $\mathrm{s}$ & $\mathrm{j}$ & & $\mathrm{h}$ \\
Nasal & $\mathrm{m}$ & $\mathrm{n}$ & $\mathrm{n}$ & & \\
Lateral & & $\mathrm{r}$ & & & \\
Rhotic & & $\mathrm{r}$ & & \\
Glide & $\mathrm{w}$ & & $\mathrm{j}$ & & \\
\hline
\end{tabular}

Table 2: Terena Vowels

\begin{tabular}{lccc}
\hline & Front & Central & Back \\
\hline High & i & & $\mathrm{u}$ \\
Mid & $\mathrm{e}$ & & $\mathrm{o}$ \\
Low & & $\mathrm{a}$ & \\
\hline
\end{tabular}

It has often been noticed that the language shows no synchronically transparent prefix that could be a candidate for a reflex of the PA Privative prefix *ma- (see Wise 1990: 102106; Michael 2014: 278; though see section 4 for a dissenting opinion). I will show here that traces or remnants of PA *ma- can indeed be found, absorbed within synchronically unanalyzable forms and therefore instantiating 'phonogenesis' (Hopper 1994) or 'demorphologization' (Hopper 1990). Before proceeding to the core of the paper, though, and setting the background for the presentation of the specific claims and contributions advanced here, section 2 offers a general discussion of relevant points concerning the PA Privative prefix *ma-.

Unless explicitly noted otherwise, data on Terena come from my own fieldwork at the Cachoeirinha reservation, Mato Grosso do Sul, Brazil; I will, of course, rely on many other sources on the language. Data from other Arawakan languages comes from diverse published sources that will be cited accordingly.

\section{The privative prefix *ma-}

No general survey of the Arawakan language family fails to mention the existence, in virtually every member language, of a prefix reflecting the PA Privative prefix *ma- (see e.g. Matteson 1972: 164; Wise 1990; Payne 1991; Aikhenvald 1999: 95, 2009: 61). This prefix is usually attached to nouns, often dependent/inalienable nouns, such as body-part or kinship terms, and derives a one-place predicate ("adjective") or noun which denotes an entity or object that is characterized by lacking the referent of the base noun. Aside from nouns, reflexes of *ma- are often found attached to stative predicates, as shown in the 

examples below from two rather distant members of the family, Paresi, of central Brazil, and Lokono, of the Caribbean branch. ${ }^{3}$

(2) Reflexes of PA *ma- in Paresi and in Lokono:

(a) Paresi

(based on Brandão 2014: 358)

ma-initjo-hare

PRIV-mother-NMLZ.FEM

'not having a mother'

ma-kirane-hare

PRIV-be.small-NMLZ.FEM

'not being small'

(b) Lokono

(based on Patte 2014)

ma-sa- $\mathrm{t}^{\mathrm{h}} \mathrm{O}$

PRIV-child-NMLZ.FEM

'female without child, childless woman'

ma-seme- $\mathrm{t}^{\mathrm{h}} \mathrm{O}$ to

PRIV-be.sweet-NMLZ.FEM DEM.FEM

'this is not sweet'

These prefixes are described as historically stable nominal and verbal negative markers (Aikhenvald 1999: 95) and as one of the clearest cases of a grammatical morpheme reconstructible to the PA ancestral language (Michael 2014: 276). Michael (2015) offers compelling arguments in favor of reconstructing for PA *ma- a function of deriving denominal Privative predicates, with later extensions, in many daughter languages, where reflexes of *ma- may also function as standard negation operators.

Forms relatable to PA *ma- are indeed so widespread that whenever the status of a language as Arawakan was felt to be uncertain or only superficially established, or whenever new and improved documentation became available on a language otherwise thought to be Arawakan, the identification of a formally similar prefix having a 'negative' or 'privative' meaning was many times offered as a compelling piece of evidence for the Arawakan affiliation of the language in question (e.g. Taylor 1954: 153 on Taino; Taylor 1957: 298 on Island Carib and Taylor 1977: 58-59 on Palikur). Its use as a diagnostic Arawakan feature is thought to be even stronger when accompanied by reflexes of the equally widespread prefix *ka- 'Attributive' (see in particular Mosonyi 1993: 170). ${ }^{4}$ Payne

${ }^{3}$ The following abbreviations are used here in glosses: PRIV $=$ Privative, NMLZ $=$ Nominalizer, FEM $=$ Feminine, MAS $=$ Masculine, $\mathrm{DEM}=$ Demonstrative; $\mathrm{OBJ}=$ Object Marker; $\mathrm{DSC}=$ Descriptive Marker; $\mathrm{PRED}=$ Predicative Marker; NEG $=$ Negation; $3=$ third person, $1 \mathrm{SG}=$ first person singular.

${ }^{4}$ Mosonyi (1993) is one of the studies to discuss * $k a$ - and *ma- as paradigmatically opposed or contrasting morphemes. Aikhenvald (2009: 61) also speaks of "the negative prefix $m a$ - and its positive counterpart". Whether this characterization of the relation between * $k a$ - and *ma- is correct or not, in individual daughter languages or at the proto-language level, remains an open issue. See Rose (2014) on Mojeño, and Patte (2014) on Lokono for some discussion. 
(1991: 377) reconstructs *ma- 'Privative (lacking, not having)' and *ka- 'Attributive (having)' for Proto-Arawakan language, with reflexes attested in most daughter languages. Earlier, Matteson (1972: 164) also mentioned the existence of these two prefixes, proposed tentative reconstructed forms and noted that reflexes of the Attributive prefix are more common than those of the Privative.

The fact that Terena is one among the few languages of the family lacking a reflex of this prefix has been known for some time. Derbyshire (1986: 504) mentions Paresi, Waurá and Terena, the first two showing reflexes of both PA *ka- 'Attributive' and PA *ma- 'Privative', while Terena would differ in having ko-/ka- only. In the comparative survey of Arawakan morphosyntax of Wise (1990), the author cites only the languages of the Campa branch as definitely lacking reflexes of PA *ma-; accordingly, these languages show an ' $\mathrm{X}$ ' in her column dedicated to reflexes of this morpheme (Wise 1990: 102, 106). Terena, though figuring in her sample and not contributing a cognate prefix, is simply given with an empty cell in the relevant table, which stands for a clear albeit slightly implicit recognition of the fact that no reflex of PA *ma- exists in the language. Michael (2014: 278) lists Terena, along with Añun, Yanesha', Warekena and the languages of the Campa branch as languages that lack productive reflexes of this prefix. ${ }^{5}$

Both my fieldwork data and published descriptions of the language (e.g. Ekdahl \& Butler 1979: 74-75) show that such Privative meanings are expressed in Terena by means of the standard Negation marker áko, usually analyzed as an independent phonological and grammatical word, that modifies an inalienable or bound noun bearing a marker for Person/Number features of the possessor (which is $\varnothing$ - for third person). Thus:

(3) Expression of Privative meaning with bound/inalienable nouns in Terena.

(a) noi $\int o-a$ hójeno áko-ti Ø-tâki

see.1 1sG-OBJ man NEG-DSC 3-arm

"I see/saw an armless man"

(b) áko Ø-tûti ne hójeno kaliwôno

NEG 3-head/hair PRED man child

"the boy is bald"

(c) áko wỗu

NEG hand.1SG

"I have no hand(s)"

In (a) above, ákoti Ø-tâki could be glossed as "lacks (his) arm", as the Negative marker is perhaps better analyzed as a predicate meaning 'there is not' (this is noted explicitly by Ekdahl \& Butler 1979: 75). The whole expression seems to function then as a kind of clause modifying hójeno 'man'. In (b) áko 'there is not' functions as a main clause predicate, with the usual clause-initial position reserved for verbs in the language and forming a nominal predicate with the noun -t $\hat{u} t i$ 'head; hair', marked in turn with a 3

${ }^{5}$ Kinikinau is also listed as a separate language, though this is arguably a co-dialect of the same language as Terena (see Carvalho 2016). 
person $\varnothing-{ }^{6}$ The example in (c) also underscores the verbal character of áko 'there is not' and shows the possessive marking for $1 \mathrm{sG}$ in the noun -wôu 'hand'.

Thus, while the presence of a Privative/Negative prefix with a form derivable from *ma- is certainly 'widespread' in the family (Aikhenvald 1999: 95), being found in the 'overwhelming' majority of Arawakan languages (Aikhenvald 2009: 61), some member languages lack any reflex of this marker. As shown in the remainder of the paper, however, Terena can be added to the list of Arawakan languages, such as those of the Kampan branch (Michael 2014: 212; 2015), where remnants of the privative *ma- can be found fossilized in certain unanalyzable roots.

\section{Terena mojénoti 'orphan' and mofều 'barren, sterile, especially of animals, but also for women'}

The earliest attestation of both nouns seems to be found in the unpublished dictionary of Ekdahl \& Butler (1969), where mojénoti 'orphan' and mofêu 'barren, sterile, especially of animals, but also for women' are found. Both are given as nouns in the dictionary, which recognizes an independent class of adjectives, in addition to verbs, in Terena. Formally, these correspond precisely to my 2016/2017 fieldwork data, but the meaning of mofêu differs slightly, as the Terena speakers I worked with report that it can be applied also to a childless married man. This semantic extension is clearly an innovation and, as I will argue, the original meaning of this etymon, for which cognates can be found in ProtoMojeño as well, was probably closer to the one attested by Ekdahl and Butler.

Given the discussion in section 2, the hypothesis that these two items contain fossilized reflexes of the PA Privative prefix *ma- is at least worthy of further investigation: not only do both nouns denote an entity singled out for lacking something (either parents or children/offspring), but both also have $m$ - as their initial consonant. I will justify this postulation of a Privative prefix for Pre-Terena in the following sections.

\section{1. mojénoti < *mo-ireno-ti 'one who lacks parents'}

Starting with mojénoti 'orphan', - $t i$ can be easily identified as the suffix often found in stative predicates or 'adjectives' (e.g. hijá-Pi-ti 'yellow', mómi-ti 'tired', láka$P i$ - $t i$ 'wet', kótu- $t i$ 'hot'). Though this suffix appears in one-place predicates expressing 'adjectival notions' (as in mómiti ne sêno 'the woman is tired') or in adnominal, attributive constructions (as in kótuti káfe 'a hot day'), ${ }^{7}$ it is fairly common to find Terena nouns in

${ }^{6}$ I glossed ne as a predicator (PRED) because it can function many times as the sole difference between an attributive and a predicative/clausal construction: fúnati hójeno '(a) strong man', but fúnati ne hójeno 'the man is strong' (see Ekdahl \& Butler 1979: 54). The morpheme ne, just like ra, is, however, more felicitously glossed as a Determiner, since it has both Deictic and Definiteness-related meanings, modifying the noun to its right. Much more research is required on the properties of these markers.

7 The verbal suffix - $t i$ is glossed either as a 'descriptive' (Ekdahl \& Butler 1979: 104) or instead as a clitic that attaches a progressive meaning to active verbs (Ekdahl \& Grimes 1964: 267), but denotes a state with adjectival or non-active verbs. An important question, to which I have no answer now, concerns the nature of the 
which this suffix occurs, often as a non-segmentable part of the word form, as in nâti 'chief', kopénoti 'indian (non-white)' and ihunówoti 'wind'. This use of -ti in nouns seems, however, to be derived, and probably originates in nominal ellipsis, where a head noun can be suppressed, and an epithet comes to replace it (as in the textbook example of Latin persicum mälum > persicum 'peach'). Thus, from phrases such as mojénoti kaliwôno '(an/the) orphan child', the modifying expression, mojénoti 'orphan', came to be used as the phrasal head in certain favorable pragmatic conditions. Many animal names for specific species or types, for instance, plausibly originate in such modifying epithets that qualified a more general term, as in kohipoti 'a kind of hawk' (derived from a base -hîpo- 'claw, fingernail' and the Verbalizer/Causative prefix ko-, as 'one who has claws'). The root mojéno- can function as a base for the derivation of an active verb, in which case it occurs followed by $-\int o$, one of the suffixes deriving Active verb stems (see Ekdahl \& Grimes 1964): mojéno-fo 'to orphan'. 8

Postulation of a fossilized reflex of the PA Privative prefix would call, in principle, for the parsing of -mojéno- as *mo-jeno. The root *-jeno could be matched either with -jêno 'wife', which would be semantically implausible and can be excluded on these grounds, or with -ijéno 'relative, family'. If the latter is accepted, the formal problem is easy to deal with by invoking internal sandhi, that is, the root-initial vowel $i$ is elided when preceded by the vowel of the prefix *mo-: *mo-ijeno-ti $>$ mojéno-ti. This process is likely a correlate of the lexicalization and loss of a morpheme boundary, as the synchronically productive Verbalizer/Causative prefix ko- does not trigger a similar operation: ko-íjeno-a 'to be a relative of'; moreover, the cognate of Terena *mo- in Mojeño does not trigger vowel elision either (máimaru 'bachelorette' (lit. "husbandless”); maénare 'orphan'; Olza Zubiri; Nuni de Chapi; Tube 2002: 787-788). On the semantic side, note that Terena -ijéno 'relative, family' denotes both consanguine and affinal relatives. This might be considered a weakness of the etymology though, as shown below, comparative evidence demonstrates that this semantic difficulty is illusory only.

Focusing for the moment on -ijéno 'relative, family', a look at Mojeño, arguably Terena's closest relative (see e.g. Carvalho 2017c), does not seem to help much. Ignaciano (Ott \& Ott 1983: 600) -haneana 'relative', Trinitario (Gill 1993: 25) -hanono 'relative' (also -hanemuri 'relatives', with -muri 'group'; Gill 1993: 25) and Old Mojeño <nu-

relation between this suffix and the Absolute suffix - $t i$, arguably a reflex of the PA Absolute ${ }^{*}-t f i$ reconstructed by Payne (1991: 379). Even though their formal resemblance is total, this is not in itself enough to eliminate the possibility that the similarity is a fortuitous and derivative outcome specific to Terena, one that turned two etymologically distinct morphemes into homophones. Note, for instance, that Garífuna has an Aorist suffix $-t i$, often used with adjectival predication (Quesada 2012: 115-116), being thus strikingly similar in form and function with the Terena descriptive $-t i$. In Garifuna, however, the Absolute suffix is $-i \sim-o \sim-u$ (Taylor 1956: 35) and comparison with its Lokono cognate $-h V$ (Pet 2011: 16) suggests the previous presence of a consonant.

${ }^{8}$ The verb-forming suffixes - $k o$ and -fo were described by Ekdahl \& Grimes (1964) as being analyzable in terms of a thematic consonant, $-k$ - and - - -, respectively, followed by a Realis mood marker $-o$. These suffixes are clearly cognate of the 'thematic' (Olza Zubiri et al. 2002: 76-99) or 'active' suffixes (Rose 2015: 80) -koand $-t f o$ - found in Mojeño. One of the best arguments for the two-morph analysis in Terena is the paradigmatic opposition between Realis - o- and Irrealis - $a-$; if they were not occupying the same paradigmatic slot, $-k o-a-$ and - $\int o$ - $a$ - would be expected, yet this is never found, despite the well-formedness of -oa- clusters in Terena. For simplicity's sake, however, I will keep with the analysis of Terena - ko and - $f o$ as single suffixes, as this is not immediately relevant to the present discussion. 
hane > 'my relative', call for the reconstruction of *-hane 'relative' for Proto-Mojeño, with fossilization of the Plural suffix *-ono in both Ignaciano and Trinitario (see Carvalho \& Rose 2018 for details on Proto-Mojeño). For 'orphan', the extant varieties of the language, Ignaciano and Trinitario, have watfa (Ott \& Ott 1983: 570; Gill 1993: 22), which look like Quechua loans (see Proto-Quechua *waktfa 'orphan', Emlen 2017: 334; Adelaar 2004: 379, 427 notes borrowings of this same lexeme in other languages: Atacameño or Kunza (isolate), and Yanesha' (Arawakan)). Old Mojeño shows, in addition to forms having the Privative prefix mo- affixed to either the root for 'father', -ija-, or for 'mother', -eno- (also present in some Ignaciano sources: Olza Zubiri et al. 2002: 787-788), a word meaning 'orphan of both parents' and also 'poor': <nitapohicobô > (see Marbán 1701: 255 for all three words; see Carvalho \& Rose 2018 for Proto-Mojeño *-ija 'father' and

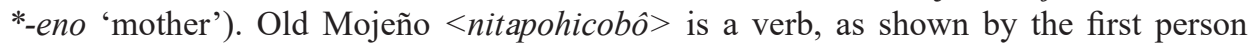
singular $n$ - and the verbal thematic/active suffix -ko-. It is clearly uninformative as far as the etymology of Terena mojénoti 'orphan' is concerned. ${ }^{9}$

A cognate of Terena -ijéno 'relative' is found, however, in (Modern) Baure -iron(o) 'parent', for which a form -irono can be easily recovered based on internal evidence (Danielsen 2007: 117). The correspondence of Baure $o$ to Terena $e$ in medial position is not problematic, as Old Baure preserves a more conservative form <nireno $>$ 'my parents' (Magio 1880 [1749]: 2; that is: ni-ireno), and there is evidence that $e>o / C o$ was a recurring development in the modern variety (see e.g. eteno > eton(o) 'woman'; Danielsen 2007: 52). That the rhotic in Baure -ireno lacks a match in the Terena cognate is also easily explainable, as ${ }^{*} r$ was regularly lost preceding any vowel other than $*_{i}$ in Terena (see Carvalho 2018a: 253-254; this particular change will be relevant in the next section as well).

The formally irreproachable match of Terena -ijéno 'family', 'relative' and Baure -ireno 'parents' furnishes the required elucidation for the semantic mismatch between Terena -ijéno 'family', 'relatives': mojéno- 'orphan'. Assuming a Pre-Terena level preceding the fossilization or absorption of the Privative *mo-, the postulation of an etymon *ijéno 'parent', supported by the external evidence of Baure -ireno 'parents', yields *mo-ijéno 'orphan' (lit. "lacking parents") as a semantically transparent derivation at this Pre-Terena stage. After that, presumably when *mo-ijéno was no longer morphologically transparent, -ijéno was subject to broadening, now meaning 'relatives', 'family' and not only 'parents'.

Though Mojeño offers no cognate of the Terena word -ijéno 'relative', it does have a functional, productive prefix that, based on the set Old Mojeño mo- (noted above), Ignaciano ma- (Ott \& Ott 1983: 38; Olza Zubiri et al. 2002) and Trinitario $m-\sim m w-$ (Rose 2014: 223-225), ${ }^{10}$ and on the known correspondences between Mojeño dialects (see

${ }^{9}$ For the sake of completeness, I note that Old Mojeño <nitapohicobồ seems to contain the verb root -ita- 'to end, be finished', which, in a stem containing the classifier -hi-, seems to derive the meaning 'ended, finished, worn out clothes' (see Ott \& Ott 1983: 241 for Ignaciano -ita-hi-Pa 'worn out clothes'). The semantic association between 'poor, destitute' and 'orphan' is both obvious and well-attested, requiring no further comment.

${ }^{10}$ According to Françoise Rose (personal communication), in the context of a following front vowel, the glide $w$ in the $m w$-variant could represent either underlying $u$ or $o$. Her own recent, first-hand data on Trinitario has revealed, however, the occurrence of $m u$ - preceding a consonant as well. The origin of this high vowel where comparative considerations make non-high $o$ the expected vowel demands further investigation. 
Carvalho \& Rose 2018), allow for the straightforward reconstruction of Privative *mo- for Proto-Mojeño (the Ignaciano variety of Mojeño shows $m a$ - instead due to the context-free merger PM $*_{o}, * a>a$ in this dialect; see Carvalho $2017 \mathrm{c}$, Carvalho \& Rose 2018).

Once the fact that a Privative $m o$ - is also found in Baure is brought into focus (see Danielsen 2007: 187-188), it is straightforward to recognize that Pre-Terena *mo- and Proto-Mojeño *mo- discussed above are all reflexes of a 'Proto-Bolivia-Paraná' Privative prefix *mo- (see the classification in (1)). This would call, in turn, to a match with its putative Proto-Arawakan etyma *ma- that implies a diachronic correspondence PA $* a>$ *o for the Bolivia-Paraná languages. Matteson (1972: 171) and Payne (1991: 472) noted that $a$ in many Arawak languages corresponds to either $a$ or $o$ in Terena and in Baure. Both authors suggest that certain coronal or palatal segments are involved in conditioning the diverse reflexes, but the precise nature of the conditioning factors behind the apparent split of PA *a in Proto-Bolivia-Paraná *a or *o remains uncertain. An adequate understanding of this and other developments will have to wait for the reconstruction of Proto-BoliviaParaná, a task beyond the goals of this paper.

What can be asserted for the moment is that $* a>o$ likely took place at the level of Proto-Bolivia-Paraná and possibly constitutes a shared innovation of this subgroup, one that accounts for the formal deviation between PA *ma- and Proto-Bolivia-Paraná *mo-. The shared character of this development was not realized by either Matteson (1972) or Payne (1991), since the former did not use any data from Mojeño, while the latter included only Ignaciano in his comparative study, exactly the Mojeño variety which, as noted above, merged $*_{o}$ and $* a$ as $a$.

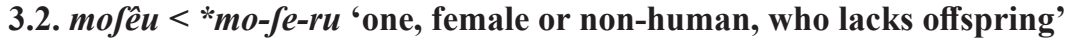

For mofêu 'barren, infertile, of women and animals', I will argue that the etymon underlying this Terena lexical item is the form *mo-fe-ru 'childless woman/infertile animal', where *mo- is the Privative prefix discussed above, *-fe is a root meaning 'offspring/child' and *-ru is a Gender-marking suffix.

Identification of the Privative $*_{m o-}$, whose existence at a Pre-Terena level was justified in the preceding section, leaves us with a 'residue' *-fêu. This is not, and has never been, a base/stem on which Terena morphology has ever operated but includes instead a root *-fe probably meaning 'offspring, children' and an inflectional suffix * $u$ carrying/realizing Gender features. This inflectional suffix seems to be selected by the prefixation of *mo- and is characteristic of certain one-place predicates, having clear parallels elsewhere in other Arawakan languages. I will try to establish these points in the remainder of the section.

The meaning 'offspring, children', or something close to it, can be assigned to *-fe given the usual operation of the Privative with bound nouns (discussed in section 2); that is: *-fê 'offspring, children', *mo-fê-u 'one who lacks offspring or children'. Languageinternal comparison with -féra 'son; boy' suggests an additional occurrence of the root, that is *e-Pa 'son; boy'. These are, however, etymological segmentations, since mofêu 'barren, infertile, of women and animals' is a synchronically unanalyzable word in modern Terena (and so is, it seems, -fé? a 'boy, son'). In the comparative front, data from Mojeño 
CARVALHO - DEMORPHOLOGIZATION OF THE PROTO-ARAWAKAN... is particularly illuminating: a PM etymon*motferu 'sterile woman' can be reconstructed in a straightforward manner based on Old Mojeño <mocheru> 'sterile woman' ('muger esteril'; Marbán 1701: 516), Trinitario mtferu 'sterile' (Gill 1993: 18) and Ignaciano matferu 'sterile' (Ott \& Ott 1983: 549). Note that in establishing the meaning of this PM etymon I have relied in the evidence from $17^{\text {th }}$ century Old Mojeño. PM *motferu 'sterile woman' is an obvious cognate of Terena mofêu 'barren, sterile, of women and animals' (see Carvalho 2018a on Terena* $r$ loss, also noted in the preceding section). Given the synchronically transparent status of the Privative mo- in all Mojeño varieties ( $m a$ - for the Ignaciano variety), it is certainly easier to isolate the formatives in *-tfe- 'offspring' at the PM level than is the case at the level of modern Terena. On the basis of the Trinitario forms -tera 'nephew' (Gill 1993: 9) and -tehi 'niece' (Gill 1993: 9), of Ignaciano -tfehi 'nephew, cousin' (Ott \& Ott 1983: 147) and of the Old Mojeño cognates <nuchehi >, <nuchera> both meaning 'My nephew' ('Mi sobrino'; Marbán 1701: 459), reconstruction of the two Proto-Mojeño etyma sharing a common base *-te- is straightforward (see table 3$).{ }^{11}$

Table 3: Proto-Mojeño etyma

\begin{tabular}{cccc}
\hline Proto-Mojeño & Trinitario & Ignaciano & Old Mojeño \\
\hline$*-t e-r a$ & $-t f e r a$ 'sobrino' & - & $<$ nuchera $>$ 'Mi sobrino' \\
$*-t f e-h i$ & $-t f e h i$ 'sobrina' & $-t f e h i$ 'sobrino' & $<$ nuchehi $>$ 'Mi sobrino' \\
\hline
\end{tabular}

Though no meaning is assigned here for the root PM*-te, the conclusion that it involves some reference to 'individual from one generation below that of Ego' seems plausible. The precise meaning of the suffixes $*_{-} r a$ and $*_{-} h i$ will remain an open issue for now.

Matching the Proto-Mojeño base *-tfe-, with a meaning related to 'younger relative', and the hypothetical Pre-Terena base *-fe-, meaning 'child(ren), offspring', raises no formal issues, as independent evidence shows that the Terena coronal fricatives reflect affricates and, of direct relevance, that Terena $\int<t$ (see Carvalho 2017a, b for details). The identity vowel correspondence is likewise regular: Proto-Mojeño (PM) *-nene 'tongue': Terena -n êne 'tongue'; PM *-ope-ra 'bone': Terena -ôpe 'bone'; PM *une 'water': Terena úne 'water'; PM *mote-hi 'soil' : Terena móte 'mud'; PM *-peno 'house (poss.)' : Terena -pêno 'house (poss.)' (see Carvalho \& Rose 2018 for the Proto-Mojeño etyma).

Assuming the cognation between the PM etymon *mo-tfe-ru 'lacking offspring' and Terena mofêu 'barren, infertile, of women and animals' as established, it is now necessary to account for the suffix *-ru of the PM form and its suggested relationship with the 'residue' $-u$ of the Terena cognate. Evidence from extant Mojeño varieties allows one to reconstruct Gender features for the suffix*-ru, or, more precisely, Feminine Gender. Though Gender in Mojeño seems to be restricted to third person singular pronouns/prefixes and to agreement with determiners (Rose 2015), traces of an early opposition between two Gender-marking suffixes (overt Gender-marking in nouns) can be found in some frozen formations or in non-productive corners of the morphology of its dialects, and this seems to parallel exactly

${ }^{11}$ As noted in Carvalho \& Rose (2018), Old Mojeño forms from Marbán (1701) that include relative/ inalienable nouns, such as body-part terms and kinship terminology, are normally given with the first person singular prefix $<n u->$. 
the widespread opposition between two Gender-marking suffixes found in most other Arawakan languages (see e.g. De Goeje 1928: 49; Matteson 1972: 162-164; Payne 1991: 377; Aikhenvald 2009: 61; Danielsen 2011: 500, 514). Thus, some structured lexical sets reveal likely remnants, as shown below in table 4 .

Table 4: Evidence for PM *-ru 'FEM' and *-re 'MAS'

\begin{tabular}{|c|c|c|c|c|}
\hline & Proto-Mojeño & Trinitario & Ignaciano & Old Mojeño \\
\hline 'widow, husbandless' & $*_{m o-i m a-r u}$ & mwimaru & máimaru & $<$ moimarú $>$ \\
\hline 'widower, wifeless' & *mo-jeno-re & mjénore & majenare & $<$ moyenoré $>$ \\
\hline
\end{tabular}

Analysis of the two cognate sets in table 4, first, Ignaciano máimaru 'widow, husbandless woman' (Ott \& Ott 1983: 271), Trinitario mwimaru 'bachelorette' (Gill 1993: 38), Old Mojeño <moimarú> 'bachelorette' ('Soltera'; Marbán 1701: 339), and, second, Ignaciano majenare 'a man having no woman' (Ott \& Ott 1983: 279), Trinitario mjénore 'bachelor' (Gill 1993: 30) and Old Mojeño <moyenoré> 'bachelor' ('Soltero'; Marbán 1701: 339), allow for the reconstruction of two PM etyma *mo-ima-ru 'widow; bachelorette' (lit. "one (female) who lacks a husband) and *mo-jeno-re 'widower; bachelor' (lit. "one (male) who lacks a wife"). The crucial fact here is that in both etyma, and their reflexes, $*_{-} r u$ marks the referent as Feminine, while *-re marks the referent as Masculine. Additionally, all Mojeño varieties retain at least one lexeme for which these suffixes retain a synchronically-transparent paradigmatic opposition as Gender-markers, the noun -iha- 'name': Ignaciano -iharu 'name of a woman' vs. -ihare 'name of a man' (Ott \& Ott 1983: 219-220); Old Mojeño <nihare> 'man's name', <niharù > 'woman's name' ('Nombre de hombre' and 'nombre de muger'; Marbán 1701: 290). Note that these PM Gender-marking suffixes, *-re 'Masculine' and *-ru 'Feminine', fit in the general pattern found throughout the family, where a -CV suffix with a round, back vowel codes the Feminine and opposes another -CV marker whose vowel is either front or at least non-back and unrounded, coding Masculine Gender. ${ }^{12}$ Thus, in Yine one has: -hniri 'husband of' vs. -hninro 'wife of'; tsri 'big/old man' vs. tsro 'big/old woman' (see Hanson 2010: 109); in Wapixana: -da-ri 'father', -da-ro 'mother' (WLP 2000: 26); Apurinã: -iri 'father', -iniro 'mother' (Facundes 2000: 161); Paresi tema-re 'runner (masc.)', tema-lo 'runner (fem.)', zanekoatya-re 'hunter (masc.)', zanekoatya-lo 'hunter (fem.)' (Brandão 2014: 204-206); Baniwa do Içana -hánili 'father', -íinili 'husband' (vs. íina.u 'woman'), -pheeli 'elder brother' (vs. -phee.lu 'elder sister'), mínali 'owner, master (masc.)' vs. mínaıu 'owner, master (fem.)', -khili 'cross-cousin' vs. -kui.,u 'cross-aunt' (Ramirez 2001: 136-137).

Matching PM *mo-tfe-ru 'infertile woman' to Pre-Terena *mo-fe- $u$ 'one who lacks offspring', allows Terena $-u$ to be explained as a cognate of the PM suffix realizing Feminine Gender. In Terena, however, this suffix is never synchronically segmentable and, therefore, just like the Pre-Terena Privative *mo-, it was entirely absorbed into (now) underived words. The occurrence of Gender suffixes, or of Nominalizing suffixes carrying Gender features, in forms derived by the prefixation of the Privative *ma- is found in

\footnotetext{
${ }^{12}$ Moreover, as shown by Payne (1991), $e$ is the most common reflex of PA $*_{i}$ in Mojeño (see Payne 1991: 470).
} 
many Arawakan languages which retain productive reflexes of this prefix. In Apurinã, for instance, Facundes (2014: 131) describes a phenomenon of 'word-internal negative "agreement", the fact that prefixation of ma- triggers the appearance of suffixes that realize Gender features, - $t u$ for Feminine and -ty for Masculine (the Privative prefix and the Gender-marking suffixes are highlighted in bold in the examples below):

(4) Apurinã Negative Agreement (Facundes 2014).

$\begin{array}{lll}\text { (a) sytu } & \text { m-ỹtanyry-tu } & \text { apuka } \\ \text { woman } & \text { PRIV-husband-NEG.FEM } & \text { arrive } \\ \text { "The unmarried (deprived of husband) } & \text { woman arrived" } \\ \text { (b) amaryny } & \text { m-yry-ty } & \text { apuka } \\ \text { child } & \text { PRIV-father-NEG.MAS } & \text { arrive } \\ \text { "The fatherless (deprived of father) child arrived" }\end{array}$

The same characteristic association between the Privative and Gender-marking suffixes is described in Brandão (2014b: 180-181) for Paresi (see the examples in (2)). In the Trinitario dialect of Mojeño, Terena's closest relative, prefixation of the Privative is often, though not always, accompanied by the suffixation of -re, a suffix that may be a cognate of Gender-marking suffixes in other Arawakan languages, though the matter deserves further investigation. A more detailed study of the morphology and syntax of the PA Privative marker *ma- and of its reflexes is needed in order to explain why is it that a Gender-marking suffix appears in some cases (such as *mo-fê-u) though not in other (such as *mo-ijéno-ti).

Finally, on the semantic side, the observations above on the etymologization of *mo$\int \hat{e}-u$ as likely involving a Feminine Gender-marking suffix $*_{-} u\left(<*_{-r u}\right)$ suggests that the meaning of mofêu attested in Ekdahl \& Butler's (1969) dictionary, 'barren, sterile, of animals and women' is the etymological one, while the translation I obtained recently in the field, according to which mofêu can also apply to men, is more innovative and a result of semantic broadening.

\section{Implications and comparison with previous claims}

As advanced in section $\mathbf{2}$, most reference sources on the Arawakan language family agree in listing Terena among the languages that have no clear reflex of the Privative prefix *ma- reconstructed for Proto-Arawakan. One source, however, lists a prefix $o$ - as the supposed reflex of $\mathrm{PA} * m a-$ in the language, claiming in addition that in the Terena privative "the consonant was dropped" (Danielsen, Dunn \& Muysken 2011: 177). The source for the authors' judgment on the existence of a Privative prefix $o$ - in Terena is left unspecified; what can be established, as we have shown here, is that PA *ma- or, better said, its Bolivia-Paraná reflex *mo-, was absorbed as part of certain roots in the language and has no other morphologically autonomous reflex. Based on the etymologies advanced in section 2, any alternative hypothesis on the reflexes of *ma- in Terena can, therefore, be rejected. 
The reconstruction of a Privative prefix *mo- for Pre-Terena allows for the etymologization of other forms that might look formally or semantically difficult on either internal or comparative grounds. The Terena adjective -mowó-?i-ti 'dry', as in mowó 'iti ne ra kareúke 'the beans have dried' (Silva 2013: 208), ${ }^{13}$ lacks a semantically-matched cognate in Mojeño (see -oohi 'dry' in Trinitario; Gill 1993: 37; -áhi- in Ignaciano; Ott \& Ott 1983: 622). In Ignaciano one does find, however, máwaku 'empty' (Ott \& Ott 1983: 278) which, compared to Trinitario mowku 'empty' (Gill 1993: 29) and Old Mojeño <mobocu> 'estar vacio' (Marbán 1701: 515), allows for the trivial reconstruction of a Proto-Mojeño form *mowoku 'empty'. In turn, PM *mowoku 'empty' can be analyzed as *mo-owo-ku, with the Privative *mo- prefixed to the verb root *-owo- 'to be, stay' (cf. Terena -ôwo 'to be, stay') and the suffixation of the classifier $-k u$ for cavities and holes (see Olza Zubiri et al. 2002: 202; cf. Terena ówoku 'house', that is, owo-ku). ${ }^{14}$ Note also Ignaciano ka-awa-ku 'to be filled, to have something in' (Ott \& Ott 1983: 131), with the opposite prefix ka- (see section 2). ${ }^{15}$ So, PM *mo-owo- $k u$ 'empty, lacking content' retains a clearly transparent meaning. In Terena, however, mówo- 'dry' shows the effects of a semantic shift 'empty'> 'dry', perhaps from the specialized use of 'empty' as meaning 'empty of water', no doubt promoted by resulting lack of semantic transparency caused by the loss of the Privative *mo- as a synchronic morpheme. ${ }^{16}$

It is expected that further cases of lexical items having fossilized instances of the *mo- prefix will turn up after additional scrutiny. The case of mone 'thirst', attested in Silva (2013: 208) is straightforward: an analysis involving mo-une 'lacking water' suggests itself naturally and is in fact corroborated by the earlier attestations of $<$ moone $>$ 'Durst' in Schmidt (1903: 597; note the long vowel) and more strikingly by moune 'thirst' (Ekdahl \& Butler 1969). In fact, the dissolution of the etymological diphthong mo-une $>$ mo-ne by elision of the root vowel is entirely parallel to that required in section $\mathbf{2 . 1}$ in the analysis of mojénoti 'orphan'. This somewhat unexpected (see 2.1) and extreme phonological reduction that accompanies the loss of the independent morphological status of the Privative *mo- resonates with the characterization of phonogenesis or demorphologization as the last stage in grammaticalization (Hopper 1994: 31) where the concurrence of semantic bleaching and phonological reduction is considered almost definitional of the process.

Other instances in which PA *mo- might have been absorbed are much less clear and, for this reason, I will do little more than listing some of them, as thorough etymologization

${ }^{13}$ I have adapted the transcription used in Silva (2013), as the accentual diacritics are not employed in this source.

${ }^{14}$ See Carvalho \& Rose (2018) for a discussion of accentual patterns that also support this morphological analysis. In short, trisyllabic words in Ignaciano showing exceptional word-initial stress, like máwaku 'empty', can be always shown to be either synchronically analyzable as having a suffix, or to be etymologically derivable from forms having this specific morphological structure.

15 The specific example given by Ott \& Ott (1983: 131) is kawaku?i 'to have content (a thing)', with the classifier - $2 i$, which Olza Zubiri et al. (2002: 231) describe as a form-based classifier used with objects having a round shape and a stem or cylindric projection on the top. This makes sense of the particular example cited by Ott \& Ott (1983: 131), where kawaku?i modifies the noun jupi 'water vessel' (Spanish cántaro).

${ }^{16}$ The latest version of the CLICs database (List et al. 2018) notes six cases of languages (out of 1220) in which the concepts 'dry' and 'empty' are colexified: one Nakh-Daghestanian language, one Turkic language, the Colorado language of the Barbacoan family and three Austronesian languages. 
of these forms will demand dealing with more complex and poorly understood formal problems. The noun mókere 'deaf person', for instance, has a clearly privative meaning, but the comparison to -kêno 'ear' leaves the loss of -no unexplained, as this element has no independent morphological status (cf. PM *-kino 'ear hole'; Carvalho \& Rose 2018). An etymology relating mókere 'deaf person' to an etymon having the Privative *mo- is, therefore, hard to establish now and remains only a promising hypothesis. The noun moetôko 'type of chicken characterized by lacking feathers in the nape' (Ekdahl \& Butler 1969) invites a comparison to -tôko 'nape', yet the medial -e-between the root and the putative Privative prefix mo- defies explanation.

As a final observation, I stated in section 3.1. that both mojénoti 'orphan' and mofêu 'barren, sterile' are nouns in modern Terena, and I have offered other examples of Terena nouns that had a similar origin in stative predicates. There I proposed that these have become nouns via the well-known path whereby modifying, attributive word-forms (either described as "adjectives" or "descriptive verbs") are "promoted" via nominal ellipsis to the head position of a noun phrase. Spelling this out in greater detail, I note that comparative evidence illustrates the use, in attributive/modifying function, of the stative predicates derived by prefixation of the Privative. Rose (2014: 223-224), for instance, explicitly describes and exemplifies this use in Mojeño Trinitario:

(5) Attributive/modifying use of Privative Stative Predicates in Mojeño Trinitario

\begin{tabular}{|c|c|c|}
\hline $\begin{array}{l}\text { (a) ma-yeno-re } \\
\text { PRIV-wife-N.Poss } \\
\text { "There may be ur }\end{array}$ & $\begin{array}{l}\text { pnokni } \\
\text { DEM } \\
\text { ied Corr }\end{array}$ & $\begin{array}{l}\text { koregieroru } \\
\text { Corregidor }\end{array}$ \\
\hline (b) n-okpoj-ko & esu & 'móperu \\
\hline $\begin{array}{l}\text { 1SG-meet-ACTV } \\
\text { "I have met a dea }\end{array}$ & PRO-F & youngster \\
\hline
\end{tabular}

The same attributive use of privative stative predicates is described by Facundes (2014: 131) for the more distantly related Apurinã. There are, therefore, no obstacles for the hypothesis that this kind of structure functioned as the precursor to the ultimate development, in Terena, of nouns showing crystallized reflexes of PA *ma-. I add, finally, that the main function of the reflexes of PA *ma- throughout the Arawakan language family is the derivation of denominal privative stative predicates (see Michael 2014: 276) and this is the function reconstructed for this morpheme (Michael 2014: 285-286; 2015).

\section{Conclusions}

This paper has shown that the Proto-Arawakan Privative prefix *ma-, while absent from modern Terena as a synchronically transparent formative, has left traces of its former presence in two, and possibly more, nominal forms. Etymologization of these nouns supports a number of other statements on the history of Terena and its closest relatives. Further lexical reconstructions were provided for Proto-Mojeño, and additional confirming evidence for the loss of $*_{r}$ in Terena, except preceding $*_{i}$, was presented. 
By finding cognates of the Pre-Terena Privative *mo- in the other Bolivia-Paraná languages, I provided further evidence on the shared development of PA $* a>o$, of still unclear conditioning, for the Bolivia-Paraná languages. This fact was only hinted at in the previous comparative literature. Moreover, these comparanda also underscore the fact that the obsolescence of PA *ma- and their absorption into a few lexical elements, which is found in both Terena and in the Campa branch (see Michael 2014: 287) constitutes an independent development. Finally, recovering Pre-Terena *mo- refutes the claim, advanced in Danielsen, Dunn \& Muysken (2011: 177), that PA $*_{m a-}>o$ - in Terena.

Two other hypotheses that open additional pathways for research were also framed and supported by some initial evidence. First, Terena nouns showing morphology that seems apparently restricted to one-place ('descriptive') predicates, in particular the Descriptive suffix $-t i$, were analyzed as having their origin in modifying (attributive) expressions "promoted" to Noun Phrase heads via nominal ellipsis. Second, the widespread opposition between two Genders marked by suffixes in Arawakan languages was tentatively reconstructed for Proto-Mojeño on the basis of some residual, non-productive patterns in the extant dialects, and a cognate of the Proto-Mojeño Feminine suffix *-ru was identified in the Pre-Terena etymon *mo-fe-ru "one, Female or non-human, who lacks offspring". These points were all carefully argued for, but will certainly benefit from additional investigation.

\section{References}

Adelaar, Willem (2004). The Languages of the Andes. Cambridge: Cambridge University Press.

Aikhenvald, Alexandra Y. (1999). The Arawak language family. In R. M. W. Dixon; Alexandra Aikhenvald (eds.). The Amazonian Languages, pp. 65-106. Cambridge: Cambridge University Press-

Aikhenvald, Alexandra Y. (2009). Arawak languages. In Keith Brown; Sarah Ogilvie (orgs.). Concise Encyclopedia of Languages of the World, pp. 59-61. Oxford: Elsevier.

Brandão, Ana Paula (2014a). A reference grammar of Paresi-Haliti (Arawak) (Doctoral Dissertation). University of Texas at Austin. http://hdl.handle.net/2152/24847

Brandão, Ana Paula (2014b). Standard and non-standard negation in Paresi. In Lev Michael; Tania Granadillo (eds.) Negation in Arawak Languages, pp. 169-183. Leiden: Brill.

Carvalho, Fernando O. de (2016). Terena, Guaná, Chané and Kinikinau are one and the same language: Setting the record straight on Southern Arawakan linguistic diversity. LIAMES-Línguas Indigenas Americanas 16 (1): 39-57. doi: https://doi.org/10.20396/liames.v16i1.8646165

Carvalho, Fernando O. (2017a). Fricative debuccalization and primary split in Terena (Arawak) historical phonology. International Journal of American Linguistics 83(3): 509-537. doi: https://doi. org/10.1086/691587

Carvalho, Fernando O. (2017b). Philological evidence for phonemic affricates and diachronic debuccalization in early Terena (Arawakan). Bol. Mus. Para. Emílio Goeldi 12(1): 157-171.

doi: http://dx.doi.org/10.1590/1981.81222017000100009 


\section{CARVALHO - DEMORPHOLOGIZATION OF THE PROTO-ARAWAKAN...}

Carvalho, Fernando O. (2017c). On Terena (Arawakan) -pâho 'mouth': Etymology and implications for internal classification. Journal of Language Relationship 15(2): 69-86.

http://www.jolr.ru/files/(216)jlr2017-15-1-2(69-86).pdf

Carvalho, Fernando O. (2018a). Arawakan-Guaicuruan language contact in the South American Chaco. International Journal of American Linguistics 84(2): 243-263. doi: https://doi.org/10.1086/696198.

Carvalho, Fernando O.; Françoise Rose (2018). Comparative reconstruction of proto-Mojeño and the phonological diversification of Mojeño dialects. LIAMES-Línguas Indigenas Americanas 18 (1): 7-48. doi: https://doi.org/10.20396/liames.v1i1.8648804

Danielsen, Swintha (2007). Baure: An Arawak language of Bolivia. Indigenous Languages of Latin America (ILLA), vol. 6. Leiden: CNWs.

Danielsen, Swintha (2011). The personal paradigms in Baure and other Southern Arawakan languages. International Journal of American Linguistics 77(4): 495-520. doi: 10.1086/662154

Danielsen, Swintha; Dunn, Michael; Muysken, Pieter Muysken (2011). The spread of the Arawakan languages: A view from structural phylogenetics. In Alf Hornborg; Jonathan Hill (eds.) Ethnicity in ancient Amazonia: Reconstructing past identities from Archaeology, Linguistics and Ethnohistory, pp. 173-195. The University Press of Colorado.

De Goeje, C. H. (1928). The Arawak language of Guiana. Cambridge: Cambridge University Press.

Derbyshire, Desmond (1986). Comparative survey of morphology and syntax of Brazilian Arawakan. In Desmond Derbyshire; Geoffrey K. Pullum (eds.) Handbook of Amazonian Languages, vol 1, pp. 469-566. Berlin: Mouton de Gruyter.

Ekdahl, Elizabeth; Grimes, Joseph (1964). Terena verb inflection. International Journal of American Linguistics 30(3): 261-268.

Ekdahl, Elizabeth; Butler, Nancy (1969). Terêna dictionary. Arquivo Linguístico 095. Brasília: Summer Institute of Linguistics.

Ekdahl, Elizabeth; Butler, Nancy Butler (1979). Aprenda Terêna. Summer Institute of Linguistics. https://www.sil.org/system/files/reapdata/13/73/81/137381525885585092541650575813160405071/ ter_Aprenda_Terena_2012.pdf

Emlen, Nicholas Q. (2017). Perspectives on Quechua-Aymara contact relationship and the lexicon and phonology of Pre-Proto-Aymara. International Journal of American Linguistics 83(2): 307-340. https://doi.org/10.1086/689911

Enger, Hans-Olav (2011). Inflectional change, 'sound laws' and the autonomy of morphology: The case of Scandinavian case and gender reduction. Diachronica 30(1): 1-26. doi: 10.1075/dia.30.1.01eng

Facundes, Sidney (2000). The language of the Apurinã people of Brazil (Doctoral dissertation). sUNY at Buffalo. https://arts-sciences.buffalo.edu/content/dam/arts-sciences/linguistics/AlumniDissertations/Facundes\%20 dissertation.pdf

Facundes, Sidney (2014). Negation in Apurinã (Arawak). In Lev Michael; Tania Granadillo (eds.) Negation in Arawak Languages, pp. 121-146. Leiden: Brill. 
Gill, Wayne (1993). Diccionario Trinitario-Castellano. San Lorenzo de Mojos: Misión Nuevas Tribus. http://www.bibvirtual.ucb.edu.bo/etnias/digital/106000524.pdf

Hanson, Rebecca (2010). A grammar of Yine (Piro) (Ph.D. dissertation). La Trobe University. http://arrow.latrobe.edu.au:8080/vital/access/manager/Repository/latrobe:37856

Hopper, Paul (1990). Where do words come from? In William Croft; Keith Denning; Suzanne Kemmer (eds.). Studies in Typology and Diachrony, pp. 151-160.Amsterdam: John Benjamins.

Hopper, Paul (1994). Phonogenesis. In William Pagliuca (ed.) Perspectives on grammaticalization, pp. 29-45. Amsterdam: John Benjamins.

Koch, Harold (2003). Morphological reconstruction as an etymological method. In Barry Blake; Kate Burridge; Jo Taylor (eds.). Historical Linguistics 2001, pp. 271-292. Amsterdam: John Benjamins.

Koch, Harold; Hercus, Luise (2013). Obscure vs. Transparent cognates in Linguistic reconstruction. In Robert Mailhammer (ed.). Lexical and Structural Etymology, pp. 35-92. Berlin: De Gruyter Mouton.

List, Johann-Mattis; Greenhill Simon J.; Anderson, Cormac; Mayer, Thomas; Tresoldi. Thiago; Forkel (eds.). (2018). Database of cross-linguistic colexifications. Jena: Max Planck Institute for the Science of Human History. Available online at clics.clld.org, accessed on 1/08/2018.

https://doi.org/10.1515/lingty-2018-0010

Magio, Antonio (1749). Arte de la lengua de los indios Baures de la Provincia de Moxos. 1880 edition by L. Adam, C. Leclerc. Paris: Maisonnneuve.

Malkiel, Yakov (1954). Etymology and the structure of word families. Word 10: 265-174.

Malkiel, Yakov (1976). The interlocking of etymology and historical grammar. Proceedings of the Second International Conference of Historical Linguistics, pp. 285-312.Tucson, January 1976. Amsterdam: North Holland.

Marbán, Pedro (1701). Arte de la lengua Moxa, con su vocabulario, y Cathecismo. Lima : Imprenta Real de Joseph de Contreras.

Matteson, Esther (1972). Proto-Arawakan. In Esther Matteson, Alva Wheeler, Frances Jackson, Nathan Waltz; Diana Christian (eds.) Comparative Studies in Amerindian Languages, pp. 160-242. The Hague: Mouton.

Michael, Lev (2014). A typological and comparative perspective on negation in Arawak languages. In Lev Michael; Tania Granadillo (eds.). Negation in Arawak languages, pp. 241-300. Leiden: Brill: 241-300.

Michael, Lev (2015). Reconstruction and historical development of the Proto-Arawakan Privative *ma-. Presentation at the Workshop on the Diachronic Syntax of South American Languages, May 28-30, 2015, Lyon: France.

Mosonyi, Esteban (1993). Algunos problemas de clasificación de las lenguas Arawak. In María Emilia Rodríguez de Montes (ed.). Estado actual de la clasificación de las Lenguas indigenas de Colombia. Bogotá: Instituto Caro y Cuervo.

Olza Zubiri, Jesús; Nune de Chapi, Conchita; Juan, Tube (2002). Gramática Moxa Ignaciana (Morfosintaxis). Caracas: Universidad Católica Andrés Bello. 


\section{CARVALHO - DEMORPHOLOGIZATION OF THE PROTO-ARAWAKAN...}

Ott, Willis; Ott, Rebecca Brake de (1983). Diccionario Ignaciano con apuntes gramaticales. Cochabamba: Instituto Lingüístico de Verano. https://www.sil.org/system/files/reapdata/75/70/42/75704259799025203588472766406243636083/18865.pdf

Patte, Marie-France (2014). Negation in Guianese Lokono/Arawak. In Lev Michael; Granadillo, Tania (eds.). Negation in Arawak languages, pp. 54-73. Leiden: Brill.

Payne, David (1991). A classification of Maipuran (Arawakan) languages based on shared lexical retentions. In Desmond Derbyshire; Geoffrey K. Pullum (eds.). Handbook of Amazonian Languages, vol. 3, pp. 355499. Berlin: Mouton de Gruyter.

Pet, Willem (2011). A grammar sketch and lexicon of Arawak (Lokono Dian). SIL e-books. Summer Institute of Linguistics. https://www.sil.org/resources/publications/entry/43236

Quesada, Diego (2012). Morfología del verbo Garífuna. Letras 1(51): 91-127. http://www.revistas.una.ac.cr/index.php/letras/article/view/5979/5874

Ramirez, Henri (2001). Uma gramática do Baniwa do Içana (Manuscrito não publicado).

Rose, Françoise (2014). Negation and irrealis in Mojeño Trinitario. In Lev Michael; Tania Granadillo (eds.). Negation in Arawak languages, pp. 216-240. Leiden: Brill.

Schmidt, Max. 1903. Guaná. Zeitschrift für Ethnologie 35, 2/3: 324-336; 4: 560-604.

Silva, Denise (2013). Estudo lexicográfico da língua terena: Proposta de um dicionário bilíngue terenaportuguês (Tese de doutorado em linguística e língua portuguesa). Araraquera, SP.: Universidade Estadual Paulista «Júlio de Mesquista Filho», Faculdade de Ciências e Letras. https://repositorio.unesp.br/bitstream/handle/11449/102358/silva_d dr arafcl.pdf?sequence=1

Taylor, Douglas (1954). A note on the Arawakan affiliation of Taino. International Journal of American Linguistics 20 (2): 152-154.

Taylor, Douglas (1957). On the affiliation of "Island Carib". International Journal of American Linguistics 23 (4): 297-302.

Taylor, Douglas (1977). A note on Palikur and Northern Arawakan. International Journal of American Linguistics 43(1): 58-60.

Wise, Mary Ruth (1990). Valence-Changing affixes in Maipuran Arawakan languages. In Doris Payne (ed.). Amazonian Linguistics: Studies in Lowland South American Languages, pp. 89-116. Austin: Texas University Press.

Wapishana Language Project (2000). Scholar's dictionary and grammar of the Wapishana language. Porto Velho: Summer Institute of Linguistics. https://www.sil.org/resources/archives/13458

Recebido: 8/11/2018

Versão revista e corrigida: 3/3/2019

Aceito: 22/3/2019. 